\title{
Perbedaan Pemahaman Konsep Siswa sebagai Hasil Penerapan Model Pembelajaran LC 5E-Analogi dan LC 5E
}

\author{
Gusti Wahyuni $^{1}$, Suhadi Ibnu ${ }^{1}$, Suharti ${ }^{1}$ \\ ${ }^{1}$ Pendidikan Kimia-Universitas Negeri Malang
}

\begin{tabular}{l}
\hline INFO ARTIKEL \\
\hline Riwayat Artikel: \\
Diterima: $21-03-2019$ \\
Disetujui: $24-04-2019$ \\
\hline
\end{tabular}

Kata kunci:

$L C 5 E$;

LC 5E-analogy;

concept understanding;

$L C 5 E$;

LC 5E-analogi;

pemahaman konsep

\author{
Alamat Korespondensi: \\ Gusti Wahyuni \\ Pendidikan Kimia \\ Universitas Negeri Malang \\ Jalan Semarang 5 Malang \\ E-mail: gustiw39@gmail.com
}

\begin{abstract}
This research aims to see differences in students' conceptual understanding of the reaction rate material as the result of LC 5E-Analogy learning model. LC 5EAnalogy is related to double coding theory, information received by learner is obtained through one of two channels, where LC 5E is expected to facilitate students to obtain information from the enggament phase to the elaboration phase, while the analogy is expected to visualize the submicroscopic aspect, so as to improve understanding of concepts students. This study uses a reasoned multiple choice test instrument that has $91 \%$ content validity with a very good category and a reliability coefficient of 0.799 in the high category. The research was conducted in two classes of XI Science at SMAN 9 Malang. Analysis of the data using the Man Whitney U Test, and the Effect Size test to see the meaning of differences in understanding of students' concepts. The results showed that there were differences students understanding in both research classes, where the difference in the values of the two classes (Sig.2-tailed 0.002) and the Effect Size $(\mathrm{d}=0.74)$.
\end{abstract}

ABSTRAK

\begin{abstract}
Abstrak: Penelitian ini bertujuan untuk melihat perbedaan pemahaman konsep siswa pada materi laju reaksi sebagai hasil penerapan model pembelajaran $L C 5 E$-Analogi. Pemahaman konsep diperlukan siswa untuk memahami materi laju reaksi, sehingga siswa dapat menjelaskan fenomena serta penerapan laju reaksi dalam kehidupan seharihari. LC 5E-Analogi berdasarkan theory double coding yaitu informasi yang diterima seseorang diperoleh melalui salah satu dari dua channel, dimana $L C$ 5E diharapkan dapat memudahkan siswa memperoleh informasi dari fase enggament hingga fase elaboration, sedangkan analogi diharapkan dapat memvisualisasikan aspek submikroskopik sehingga meningkatkan pemahaman konsep siswa. Penelitian ini menggunakan instrument tes pilihan ganda beralasan yang memiliki validitas isi $91 \%$ dengan kategori sangat baik dan koefisien reliabilitas 0,799 dengan kategori tinggi. Sampel penelitian terhadap dua kelas yang diambil dari keseluruhan kelas XI IPA di SMAN 9 Malang. Analisa data menggunakaan Man Whitney U Test, serta uji Effect Size untuk melihat kebermaknaan perbedaan pemahaman konsep siswa. Hasil penelitian menunjukkan ada perbedaan pemahaman konsep siswa pada kedua kelas penelitian, dimana nilai perbedaan kedua kelas (Sig.2-tailed 0,002) dan nilai Effect Size (d=0,74) dengan kriteria sedang.
\end{abstract}

Laju reaksi merupakan materi terkait dengan cepat lambatnya suatu reaksi kimia berlangsung atau perubahan materi reaktan dan produk tiap satuan waktu (Silberberg, 2007). Setiap reaksi kimia mempunyai laju reaksi berbeda-beda. Pada materi laju reaksi terdapat konsep-konsep dasar meliputi konsep laju reaksi, hubungan laju reaksi dengan waktu reaksi, ungkapan laju reaksi, teori tumbukan, energi aktivasi, faktor-faktor yang memengaruhi laju reaksi, serta orde dan persamaan laju reaksi (Budiarto, 2015). Konsep ini sangat penting bagi siswa untuk memahami fenomena kimia dalam kehidupan sehari-hari dan menjelaskan dari sudut pandang kimia sebagaiamana terjadi (Kolomuç \& Tekin, 2011). Hasil analisis terhadap laju reaksi didapatkan bahwa laju reaksi memuat konsep yang abstrak, konsep terdefinisi, hubungan matematis, grafik dan melibatkan multipresentasi (makroskopik, submikroskopik, dan simbolik). Karakteristik laju reaksi membuat siswa sulit memahami materi tersebut. Hal ini didukung hasil analisis dari Çalik, Kolomuç, \& Karagölge (2010) yang mengindentifikasi beberapa masalah yang dihadapi dari pembelajaran konsep laju reaksi yaitu (1) ketidakmampuan untuk mendefiniskan laju reaksi, (2) kesalahpahaman, penyalagunaan atau salah mengaitkan hubungan antara laju rekasi dan faktor-faktor yang memengaruhi, (3) kurangnya 
pemahaman tentang bagaiamana hubungan energi aktivasi dan entalpi dengan laju reaksi. Menurut Susanti (2015) pada materi laju reaksi didapatkan sebagian besar tingkat pemahaman algoritmik (perhitungan) siswa lebih tinggi dibandingkan dengan tingkat pemahaman konseptual, hal ini dikarenakan model pembelajaran yang diterapkan di dalam kelas kurang memfasilitasi siswa dalam belajar pemahaman materi secara mendalam, dan lebih cenderung kepada pembelajaran matematis sehingga siswa susah mengaitkan ketiga representasi.

Hasil analisis ini berdampak kepada rendahnya pemahaman konsep siswa terhadap materi laju reaksi. Ketika pemahaman konsep siswa rendah, maka berdampak kepada kemampuan siswa untuk menjelaskan fenomena yang berkaitan dengan materi juga rendah, dan berpengaruh kepada kemampuan argumentasi siswa. Situasi ini tidak sesuai dengan harapan yang ingin dicapai dalam proses pembelajaran, dimana siswa dapat terlibat secara aktif dan langsung dalam setiap kegiatan pembelajaran, untuk itu diperlukan suatu alternatif, salah satunya dengan menerapkan pembelajaran konstruktivistik.

Pembelajaran konstuktivistik berpadangan bahwa pengetahuan dibangun sendiri oleh siswa berdasarkan struktur pengetahuan yang telah ada dari diri siswa (Iskandar, 2011). Proses aktivitas pembelajaran siswa secara aktif disusun berdasarkan struktur kognitif yang dimiliki siswa sehingga siswa dapat mengkaitkan informasi barunya dengan stuktur kognitif yang dimilikinya dan juga mengakibatkan informasi baru yang didapatkan tersimpan dalam memori ingat dalam jangka panjang (Jauhar, 2011). Salah satu model pembelajaran konstruktivistik yaitu LC 5E.

Model pembelajaran $L C$ 5E membangun pengetahuan siswa berdasarkan pertanyaan pengajaran yang terstruktur sejak fase engagement hingga fase elaboration. Selain itu, model ini juga memberikan kesempatan kepada siswa untuk mendiskusikan ide-ide mereka (Rahayu, Prayitno, \& Fajaroh, 2008). Implementasi model pembelajaran LC 5E dalam pembelajaran sesuai teori konstruktisme dimana pengetahuan dibangun sendiri oleh siswa (Orhan, 2014). Model ini juga termasuk dalam bagian inquiry terbimbing dimana guru membimbing siswa terlibat secara langsung dalam setiap fase dalam proses pembelajaran.

Model pembelajaran LC 5E masih memiliki kendala dalam mengimplementasikannya, dimana hasil analisis Metin \& Ozmen (2009) menjelaskan adanya kendala pada fase enggament dan explanation yang mengakibatkan siswa kurang memahami apa yang harus dilakukan sehingga siswa mengalami kesulitan dalam menemukan dan mengajukan pertanyaan terkait materi. Johnstone (1993) menyatakan bahwa aspek submikroskopik belum dapat dijangkau oleh kemampuan berpikir siswa, hal ini dikarenakan siswa cenderung lemah dalam melakukan interpretasi terhadap fenomena yang tidak dapat dijangkau oleh panca indera sehingga diperlukan suatu bantuan analogi untuk membantu memvisualisasikan fenomena submikroskopik dan membantu membentuk pemahman konsep siswa (Gabel, 2003).

Analogi memberikan representasi submikroskopik secara tidak langsung melalui penyajian konsep analog, yang membutuhkan imajinasi siswa dalam menginterpresikan kemiripan konsep analog dengan konsep target. Harrison \& Treagust (2006) menyatkan analogi yang digunakan harus familiar bagi siswa agar lebih mudah menginterpretasikan kemiripan antara konsep target dengan konsep analog. Contohnya bola yang mengelinding pada sebuah bukit (Dreistadt, 1968). Penelitian Supasorn \& Promarak (2015) menyimpulkan pembelajaran melalui analogi sederhana dapat mengarahkan siswa memperoleh pemahaman konsep dengan baik. Berdasarkan paparan diskusi di atas bahwa LC 5E-Analogi bisa menjadi salah satu yang meningkatkan pemahaman konsep siswa perlu dilakukan penelitian melihat pemahaman konsep siswa menggunakan model pembelajaran $L C$ 5E-Analogi dengan $L C$ 5E.

\section{METODE}

Rancangan penelitian menggunakan eksperimental semu tipe posttest only control group design. Pemilihan sampel dilakukan dengan teknik Cluster Random Sampling. Sebaran kemampuan siswa diuji homogenitas dan normalitas serta uji kesamaan dua rata-rata, selanjutnya dipilih dua kelas dengan undian koin untuk menetapkan kelas eksperimen dan kelas kontrol. Berdasarkan data tersebut, kedua kelas kelas ditetapkan sebagai (1) satu kelas bertindak sebagai kelas eksperimen ( $\mathrm{N}=30$ ); (2) satu kelas bertindak sebagai kelas kontrol $(\mathrm{N}=29)$. Tes pemahaman konsep diberikan di akhir pembelajaran. Berikut skema rancangan penelitian disajikan pada tabel 1.

\section{Tabel 1. Rancangan Penelitian}

\begin{tabular}{ccc}
\hline Kelompok & Perlakuan & Posttest \\
\hline Kelas Eksperimen & $\mathrm{X}_{1}$ & $\mathrm{O}_{1}$ \\
Kelas Kontrol & $\mathrm{X}_{2}$ & $\mathrm{O}_{2}$ \\
\hline
\end{tabular}

$\mathrm{X}_{1}$ merupakan pembelajaran dengan menggunakan model pembelajaran $L C$ 5E-Analogi pada materi laju reaksi; $\mathrm{X}_{2}$ Pembelajaran dengan menggunakan model pembelajaran LC5E pada materi laju reaksi; $\mathrm{O}_{1}$ Posttest setelah dibelajarkan dengan model pembelajaran $L C$ 5E-Analogi pada materi laju reaksi; $\mathrm{O}_{2}$ Posttest setelah dibelajarkan dengan model pembelajaran $L C$ 5E pada materi laju reaksi. 


\section{HASIL}

Skor pemahaman konsep siswa diperoleh dari jawaban siswa terhadap tes pemahaman konsep materi laju reaksi yang terdiri dari 20 butir soal pilihan ganda beralasan. Berikut ini nilai rata-rata pemahaman konsep siswa pada materi laju reaksi yang ditunjukkan pada gambar 1.

Nilai Rata- Rata Tes Pemahaman Konsep

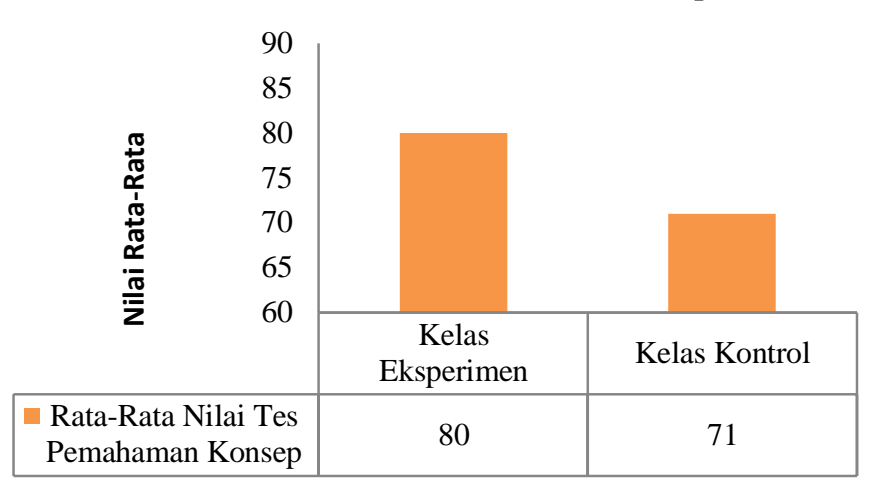

\section{Gambar 1. Nilai Rata-Rata Tes Pemahaman Konsep}

Gambar 1 menunjukkan bahwa nilai rata-rata pemahaman konsep siswa kelas eksperimen lebih tinggi dari nilai rata-rata pemahaman konsep siswa kelas kontrol, dimana selisih nilai antara kedua kelas yaitu sembilan. Hal ini memunculkan dugaan bahwa pembelajaran $L C$ 5E-Analogi memberikan dampak positif yang signifikan terhadap pemahaman konsep siswa pada materi laju reaksi dibandingkan pembelajaran $L C 5 \mathrm{E}$. Sebelum dilakukan pengujian dugaan, data tes pemahaman konsep harus diuji prasyarat untuk mengetahui analisis statistik yang digunakan pada uji hipotesis. Uji prasyarat yang dilakukan yaitu uji normalitas menggunakan Kolmogorov Smirnov dan uji homogenitas menggunakan Levene Statistic. Uji normalitas pada data tes pemahaman konsep menunjukkan bahwa data tidak terdistribusi normal. Sementara itu, uji homogenitas pada tes pemahaman konsep menunjukkan nilai sig. 0,614. Uji homogenitas ini menunjukkan bahwa data pemahaman konsep siswa dari kedua kelas homogen.

Berdasarkan hasil uji normalitas dan uji homogenitas tes pemahaman konsep siswa pada kedua kelas diperoleh uji hipotesis yaitu uji nonparametrik menggunakan Mann Whitney $U$ test dengan taraf kepercayaan $95 \%(\alpha=0,05)$. Hasil uji hipotesis data pemahaman konsep siswa ditunjukkan pada tabel 2.

Tabel 2. Hasil Uji Hipotesis Data Pemahaman Konsep

\begin{tabular}{llll}
\hline \multicolumn{1}{c}{$\mathbf{H}_{\mathbf{0}}$} & \multicolumn{1}{c}{ Kriteria Uji } & \multicolumn{1}{c}{ Hasil Uji } & \multicolumn{1}{c}{ Keputusan } \\
\hline $\mathrm{H}_{\mathrm{o}}$ : tidak ada perbedaan pemahaman & $\begin{array}{l}\mathrm{H}_{0} \text { diterima jika nilai } \\
\text { konsep antara siswa kelas eksperimen } \\
\text { dengan kelas kontrol }\end{array}$ & $\begin{array}{l}\text { Sig.(2-tailed) }=0,002, \\
\text { signifikasi }>0,05\end{array}$ & $\begin{array}{l}\mathrm{H}_{\mathrm{o}} \text { ditolak, terdapat perbedaan pemahaman } \\
\text { konsep antara siswa kelas eksperimen } \\
\text { dengan kelas kontrol }\end{array}$ \\
& $\begin{array}{l}\text { - Ho ditolak jika nilai } \\
\text { signifikasi }<0,05\end{array}$ & 0,05 &
\end{tabular}

Berdasarkan tabel 2 dapat disimpulkan bahwa pembelajaran $L C$ 5E-Analogi memberikan dampak positif yang signifikan terhadap pemahaman konsep siswa pada materi laju reaksi dibandingkan pembelajaran $L C$ 5E. Setelah itu, perbedaan pemahaman konsep siswa antara kedua kelas dilakukan uji Effect Size untuk melihat kebermaknaan perbedaan dari hasil nilai posttest pemahaman konsep siswa. Uji dilakukan untuk menunjukkan seberapa jauh pengaruh perlakuan yang kita berikan di kelas eksperimen dan kelas kontrol. Berikut ini nilai dan kriteria dari uji Effect Size disajikan pada tabel 3.

Tabel 3. Kriteria Effect Size

\begin{tabular}{|c|c|c|c|}
\hline \multirow[t]{2}{*}{ No. } & \multirow[t]{2}{*}{ Kelas } & \multicolumn{2}{|c|}{ Pemahaman Konsep } \\
\hline & & Effect Size (d) & Kriteria \\
\hline 1. & $\begin{array}{l}\text { Kelas Eksperimen } \\
\text { (LC 5E-Analogi) }\end{array}$ & 0,74 & Sedang \\
\hline 2. & $\begin{array}{l}\text { Kelas Kontrol } \\
\text { (LC } 5 \mathrm{E})\end{array}$ & & \\
\hline
\end{tabular}


Tabel 3 menunjukkan bahwa pemahaman konsep siswa juga memiliki efek sedang. Hal ini menunjukkan bahwa penyajian analogi dapat membantu siswa dalam menggambarkan fenomena submikrokopis sehingga mempermudah siswa untuk memahami laju reaksi.

\section{PEMBAHASAN}

Pemahaman konsep siswa kelas eksperimen lebih baik daripada pemahaman konsep siswa kelas kontrol. Hal ini dapat dilihat pada tabel 2, dimana diperoleh presentase rata-rata pemahaman konsep siswa yang dibelajarkan dengan LC 5E-Analogi lebih baik dari presentase rata-rata pemahaman konsep siswa yang dibelajarakan menggunakan $L C$ 5E (hasil data dapat dilihat pada gambar 1). Perbedaan pemahaman konsep dikarenakan adanya konsep yang dijelaskan dengan analogi dan tidak dijelaskan menggunakan analogi, walaupun kedua kelas diajarkan menggunakan $L C 5 \mathrm{E}$.

Pada proses $L C$ 5E, siswa dapat terlibat secara langsung dari fase enggament sampai fase elaboration dalam proses menemukan materi yang diajarkan dan siswa juga dapat mengekspos ide-ide mereka satu sama lain dalam sebuah kelompok. Analogi yang diberikan dapat memvisualisasikan materi yang bersifat submikroskopik pada materi laju reaksi. Hal ini dapat dilihat dari jawaban siswa kelas eksperimen dan kelas kontrol yang ditunjukkan pada tabel 4.

Tabel 4. Jawaban Siswa kelas Eksperimen dan Kelas Kontrol

\begin{tabular}{cll}
\hline Topik & \multicolumn{1}{c}{ Jawaban Siswa } & \multicolumn{1}{c}{ Kelas Kontrol } \\
\cline { 2 - 3 } Pembelajaran & \multicolumn{1}{c}{ Kelas Eksperimen } & \multicolumn{1}{c}{$\begin{array}{l}\text { Faktor ini disebabkan oleh luas permukaan bidang } \\
\text { sentuh, dimana serbuk mempunyai luas permukaan } \\
\text { bidang sentuh yang besar dan mengakibatkan } \\
\text { tumbukan semakin besar sehingga menghasilkan } \\
\text { produk lebih banyak dan laju reaksi lebih cepat }\end{array}$} \\
\hline
\end{tabular}

Berdasarkan tabel 4, didapatkan bahwa siswa yang dibelajarkan menggunakan LC 5E-Analogi lebih mampu menjelaskan secara lengkap tentang pengaruh luas permukaan terhadap laju reaksi dibandingkan siswa yang dibelajarkan menggunakan LC 5E. Data ini menunjukkan bahwa analogi yang diberikan melalui deskripsi verbal (berupa fenomen familiar) pada proses pembelajaran dapat memvisualisasikan secara tidak langsung suatu konsep target. Analogi membantu siswa memahami fenomena submikroskopik yang tidak dapat dilihat oleh panca indera (Ormrod, 2009). Siswa kelas eksperimen mengonstruksi konsep secara verbal dan visual (tidak langsung), sedangkan siswa kelas kontrol mengonstruksi konsep secara verbal. Paivio menyatakan siswa mencapai pemahaman yang lebih baik melalui pemerolehan informasi secara verbal dan visual (Santrock, 2014). Hal ini sesuai dengan teori double coding, dimana LC 5E membantu siswa memperoleh dan memperoses informasi-informasi yang didapatkan dari fase enggament sampai fase elaboration, sedangkan analogi membantu dalam memahami konsep yang bersifat submikroskopik. Penyajian analogi di kelas eksperimen mengkondisikan siswa lebih mudah memahami konsep daripada siswa kelas kontrol.

Penyajian analogi berupa fenomena yang familiar ke siswa merupakan salah satu usaha dalam pembentukan konsep. Ketika analogi yang diberikan familiar dengan kehidupan siswa, maka siswa tidak terlalu mengalami kesulitan dalam memahami materi tersebut, bahkan dapat meningkatkan kepercayaan diri dalam menvisualisasikan, merancang, dan menyelesaikan persamaan dan perbedaan antara fenomena dengan materi yang dipelajari sehingga konsep menjadi lebih mudah terbentuk. Hal ini disebabkan proses asimilisasi dan akomodasi pengetahuan lebih mudah dilakukan siswa karena sesuai dengan situasi dunia nyata.

Analogi yang diberikan pada fase enggament yaitu simple analogy yang mana bertujuan untuk meningkatkan keinginan tahuan siswa terhadap materi yang akan dipelajari sehingga siswa termotivasi untuk melanjutkan proses pembelajaran. Pada fase explanation dibantu dengan enriched analogy, dimana siswa diberikan suatu fenomena yang familiar dalam kehidupan sehari-hari, setelah itu siswa dimintak untuk membuat perbandingan antara domain analog dengan domain konsep target dimana tujuan untuk mengarahkan siswa berimajinasi mengenai fenomena submikroskopik. Proses pembelajaran ini membuat siswa lebih mudah memahami konsep materi pembelajaran. Analogi yang disajikan memiliki keterbatasan, dimana hanya memberikan visualisasi tertentu pada keseluruhan konsep laju reaksi kimia. Hal ini karena tidak semua fenomena submikroskopik dapat dijelaskan dengan fenomena yang familiar, sehingga diperlukan pemetaan identifikasi konsep materi dengan domain analog yang diberikan. Selain itu, pembelajaran analogi membutuhkan waktu banyak bagi siswa untuk memahami konsep analog dengan konsep target (Harrison \& Treagust, 2006).

Uraian bahasan di atas membuktikan bahwa implementasi pembelajaran dengan analogi mewujudkan pembelajaran bermakna karena dihubungkan dengan fenomena sehingga siswa dapat memperoleh pemahaamn terhadap suatu konsep secara lebih matang. Hal serupa dinyatakan oleh King (2012) yang mengemukan bahwa konsep yang matang akan dicapai ketika sains diintegrasikan dalam kehidupan sehari-hari. Dengan demikian, pembelajaran dibantu analogi dapat meningkatkan pemahaman konsep siswa. 


\section{SIMPULAN}

Berdasarkan hasil penelitian dan pembahasan dapat disimpulkan bahwa terdapat perbedaan pemahaman konsep siswa yang dibelajarakan dengan menggunakan $L C 5 \mathrm{E}$-Analogi dengan yang dibelajarkan menggunakan $L C$ 5E. pemahaman konsep siswa yang dibelajarkan dengan bantuan analogi lebih tinggi daripada yang dibelajarkan tanpa bantuan analogi. Pembelajaran LC 5E-Analogi memerlukan waktu yang lebih lama bagi siswa untuk dapat memahami kemiripan konsep analog dan dengan konsep target sehingga perlu adanya penambahan waktu untuk mengonstruksi konsep dengan analogi. Sampel penelitian sebaiknya ditambah menggunakan empat kelas penelitian agar diperoleh hasil analisis yang menyeluruh sehingga dapat dilihat pengaruh dari $L C 5 \mathrm{E}$ dan analogi.

\section{DAFTAR RUJUKAN}

Budiarto, I. D. (2015). Pengaruh Pendekatan Perubahan Konseptual dengan menggunakan Strategi POE berbantuan Analogi terhadap Pemahaman Konsep Siswa SMA pada Materi Laju Reaksi. Tesis tidak diterbitkan. Universitas Negeri Malang, Malang.

Çalik, M., Kolomuç, A., \& Karagölge, Z. (2010). The Effect of Conceptual Change Pedagogy on Students' Conceptions of Rate of Reaction. Journal of Science Education and Technology, 19(5), 422-433.

Dreistadt, R. (1968). An Analysis of the Use of Analogies and Metaphors in Science. The Journal of Psychology, 68(1), 97-116.

Orhan, E. (2014). Effect of 5 E Learning Cycle and V Diagram Use in General Chemistry Laboratories on Science Teacher Candidates' Attitudes, Anxiety and Achievement, 15.

Gabel, D. (2003). Enhancing the Conceptual Understanding of Science. Educational Horizons, 81(2), 70-76.

Harrison, A., G., \& Treagust, D. F. (2006). Teaching and Learning with Analogies: Friend or Foe? Metaphor and Analogy. Science Education, 11-24.

Iskandar, S. M. (2011). Pendekatan Pembelajaran Sains Berbasis Konstruktivis. Malang: Bayumedia Publishing.

Jauhar, M. (2011). Implementasi Paikem dari Behavioristik sampai Konstruktivistik. Jakarta: Prestasi Pustaka.

Johnstone, A. H. (1993). The Development of Chemistry Teaching: A Changing Response to Changing Demand. Journal of Chemical Education, 70(9), 701.

King, D. (2012). New Perspectives on Context-Based Chemistry Education: Using a Dialectical Sociocultural Approach to View Teaching and Learning. Studies in Science Education, 48(1), 51-87.

Kolomuç, A., \& Tekin, S. (2011). Chemistry Teachers' Misconceptions Concerning Concept. Chemical Reaction Rate, 18.

Metin, T. S., \& Ozmen, D. H. (2009). Conceptual Understanding of Causal Reasoning in Physics. International Journal of Science Education, 28(13), 1601-1621.

Ormrod, J. (2009). Psikologi Pendidikan Membantu Siswa Tumbuh dan Berkembang. Jakarta: Erlangga.

Rahayu, S., Prayitno, \& Fajaroh, F. (2008). Meningkatkan Kualitas Proses dan Hasil Belajar Kimia Dasar Mahasiswa Pendidikan Kimia UM dengan Strategi Learninng Cycle-Cooperative-5E (LCC-5E). Jurnal Pendidikan dan Pembelajaran, 15(2).

Santrock, J. (2014). Psikologi Pendidikan. Jakarta: Salemba Humanika.

Silberberg, M. S. (2007). Principles of General Chemistry. New York: The Mc Graw-Hill.

Supasorn, S., \& Promarak, V. (2015). Implementation of 5E Inquiry Incorporated with Analogy Learning Approach to Enhance Conceptual Understanding of Chemical Reaction Rate for Grade 11 Students. Chemistry Education Research and Practice, 16(1), 121-132.

Susanti, R. E. E. (2015). Pengaruh Penerapan Blended Learning Berbantuan Learning Cycle Problem Solving terhadap Pemahaman Konseptual, Algoritmik dan Grafik pada Materi Laju Reaksi. Tesis tidak diterbitkan. Universitas Negeri Malang, Malang. 